\title{
Characterization of a temperature-sensitive DNA ligase from Escherichia coli
}

\author{
Manuel Lavesa-Curto, ${ }^{1} \dagger$ Heather Sayer, ${ }^{1} \dagger$ Desmond Bullard, ${ }^{1}$ \\ Andrew MacDonald, ${ }^{1}$ Adam Wilkinson, ${ }^{2}$ Andrew Smith, ${ }^{3}$ Laura Bowater, ${ }^{3}$ \\ Andrew Hemmings ${ }^{4}$ and Richard P. Bowater ${ }^{1}$ \\ ${ }^{1}$ School of Biological Sciences, University of East Anglia, Norwich NR4 7TJ, UK \\ ${ }^{2}$ Phico Therapeutics Ltd, Babraham Hall, Babraham, Cambridge CB2 4AT, UK \\ ${ }^{3}$ Department of Biological Chemistry, John Innes Centre, Norwich NR4 7UH, UK \\ ${ }^{4}$ Schools of Biological Sciences and Chemical Sciences and Pharmacy, University of East \\ Anglia, Norwich NR4 7TJ, UK
}

Correspondence

Richard Bowater

r.bowater@uea.ac.uk

Received 29 April 2004

Revised 14 July 2004

Accepted 13 August 2004

\section{INTRODUCTION}

An essential component of DNA replication in all organisms is the joining of breaks in the phosphodiester backbone of DNA. This reaction occurs on the lagging strand of the replication fork and is performed by a ubiquitous class of enzymes known as DNA ligases (Doherty \& Suh, 2000; Lehman, 1974; Timson et al., 2000). If this end-joining reaction does not take place, the chromosomal DNA is totally degraded, and cells are no longer viable. Biochemical studies of DNA ligases purified from a variety of organisms and viruses have shown that the reaction mechanism can be broken down into three steps (Doherty \& Suh, 2000; Lehman, 1974; Timson et al., 2000). In the first step of the reaction, a covalent enzyme-adenylate intermediate is formed at a specific lysine in the catalytic motif of the enzyme (KXDG in motif I; see Fig. 3). The adenylate group can be provided either by ATP or by $\mathrm{NAD}^{+}$, leading to the classification of the enzymes as ATP- or $\mathrm{NAD}^{+}$-DNA ligases.

Within every bacterial genome sequenced to date are ORFs predicted to encode $\mathrm{NAD}^{+}$-DNA ligases of similar size and

†These authors contributed equally to this work.

Abbreviation: ts, temperature sensitive. extensive amino acid sequence homology (Wilkinson et al., 2001). $\mathrm{NAD}^{+}$-DNA ligases have been purified from many bacteria, and have similar biochemical structures and properties, but the paradigm for such enzymes is the Escherichia coli K-12 enzyme, which is a 671 amino acid, $74 \mathrm{kDa}$ protein encoded by the essential gene ligA (Ishino et al., 1986; Lehman, 1974). Microbiological and genetic analysis has confirmed that $\mathrm{NAD}^{+}$-DNA ligases are also essential for Bacillus subtilis (Petit \& Ehrlich, 2000), Staphylococcus aureus (Kaczmarek et al., 2001) and Mycobacterium tuberculosis (Gong et al., 2004; Sassetti et al., 2003). Thus, NAD ${ }^{+}$DNA ligases are likely to be indispensable to all bacteria.

Due to the essential involvement of ligA in replication, its inactivation leads to the non-viability of most bacteria. However, several temperature-sensitive (ts) strains of E. coli were isolated during the 1970s and shown to have mutations in ligA (Dermody et al., 1979; Gellert \& Bullock, 1970; Karam et al., 1979; Konrad et al., 1973; Modrich \& Lehman, 1971). E. coli GR501 is one of the most ligase-deficient of these strains, and initial characterization suggested that its ts phenotype was due to a mutation in $\operatorname{lig} A$, resulting in a reduction in DNA replication at high temperatures (Dermody et al., 1979). This conclusion has been reinforced by the observation that it can be complemented by DNA 
ligases that participate in replication in other systems, including human DNA ligase I (Kodama et al., 1991) and T7 DNA ligase (Doherty et al., 1996). Although E. coli GR501 has been particularly useful for the analysis of DNA ligase function in bacteria, there has been little characterization of the nature and biochemical consequences of the mutation in this strain.

Recently, an $\mathrm{NAD}^{+}$-DNA ligase was identified within the genome of Amsacta moorei entomopoxvirus (Sriskanda et al., 2001), although functional $\mathrm{NAD}^{+}$-DNA ligases have not been characterized in eukaryotic genomes. Thus, $\mathrm{NAD}^{+}$DNA ligases have been suggested as possible targets for broad-spectrum antibacterial compounds (Georlette et al., 2003; Gong et al., 2004; Kaczmarek et al., 2001; Lee et al., 2000; Singleton et al., 1999; Sriskanda \& Shuman, 2002). If substantial progress is to be made in the development of inhibitors that are specific to $\mathrm{NAD}^{+}$-DNA ligases, it is vital that in vivo models are utilized to test the efficacy of such compounds. This has recently been demonstrated in elegant studies of the antibacterial nature of pyridochromanones, which are good inhibitors of the LigA from several bacteria (Brotz-Oesterhelt et al., 2003; Gong et al., 2004). Complementation experiments using E. coli GR501 demonstrated that these compounds do not act on human DNA ligase I, an ATP-DNA ligase (Brotz-Oesterhelt et al., 2003). To understand the relationship of the mutation in E. coli GR501 to the structure and function of E. coli LigA, it is imperative that the molecular details of the mutation in this strain are identified. Here, we identify the mutation in the ligA gene of E. coli strain GR501, analyse its expression and overexpress the protein in a recombinant form. Biochemical analysis is used to pinpoint the molecular basis for the ts mutation in LigA from E. coli GR501.

\section{METHODS}

Growth of bacterial cultures. Strain and plasmid details are provided in Table 1. Growth of E. coli was monitored at a variety of temperatures on agar plates and in liquid cultures. In all cases, Luria broth (LB) was the nutrient medium. Antibiotics were added to media as required, with final concentrations of $100 \mu \mathrm{g}$ ampicillin $\mathrm{ml}^{-1}$ and $50 \mu \mathrm{g}$ chloramphenicol $\mathrm{ml}^{-1}$. Stock cultures containing $25 \%$ glycerol (v/v) were stored at $-80{ }^{\circ} \mathrm{C}$ and streaked onto fresh $\mathrm{LB}$ agar plates as required. Cells were made competent for DNA transformation by chemical means, and stored in $200 \mu \mathrm{l}$ aliquots at $-80{ }^{\circ} \mathrm{C}$ (Sambrook \& Russell, 2001).

At the start of each experiment, cultures containing E. coli GR501 were confirmed to be temperature sensitive. Transformations with the required plasmids were performed from glycerol stocks of competent cells maintained at $-80{ }^{\circ} \mathrm{C}$ (Sambrook \& Russell, 2001) streaked onto fresh LB agar plates (with antibiotic as required) and grown overnight at $30^{\circ} \mathrm{C}$. To assay for complementation of the ts defect, single colonies were then streaked onto two fresh LB agar plates: the plate streaked first was incubated at $43^{\circ} \mathrm{C}$ and the one streaked second was incubated at $30{ }^{\circ} \mathrm{C}$. Note that complementation by proteins expressed from pTRC99A could be achieved without addition of IPTG, indicating that expression from the strong lac-derived promoter of this plasmid was not completely inhibited in E. coli GR501.

For liquid-culture growth, single colonies from plates grown at $30^{\circ} \mathrm{C}$ were inoculated into $5 \mathrm{ml}$ liquid medium and grown overnight at $30{ }^{\circ} \mathrm{C}$. These cultures were diluted 100 -fold into $5 \mathrm{ml}$ fresh medium and incubated at the required temperature. Growth of bacteria was detected by monitoring $\mathrm{OD}_{600}$ every $30 \mathrm{~min}$ for the first $2 \mathrm{~h}$ and subsequently every $15 \mathrm{~min}$ for the remainder of the incubation period.

For analysis of the viability of the various strains harbouring different plasmids, the appropriate cultures were grown in LB (with antibiotic if required) at $30^{\circ} \mathrm{C}$ overnight. Viable cell counts were determined by plating $200 \mu \mathrm{l}$ of a $10^{-6}$ dilution of the overnight culture onto LB agar plates and counting the colonies after aerobic incubation at $30{ }^{\circ} \mathrm{C}$ or $43^{\circ} \mathrm{C}$ for $24 \mathrm{~h}$.

Table 1. Strains and plasmids used in this study

\begin{tabular}{|c|c|c|}
\hline E. coli strain & Genotype & Source/reference \\
\hline CHE30 & Hfr LAM ${ }^{-}$ptsI relA1 spoT1 bglR7 thi-1 & CGSC (Dermody et al., 1979) \\
\hline $\mathrm{DH} 5 \alpha$ & $\triangle$ lacU169 recA1 endA1 gyrA96 relA1 hsdR17 thi-1 supE44 & Lab. stock (Sambrook \& Russell, 2001) \\
\hline Plasmid & Description, antibiotic resistance & Source/reference \\
\hline pET-16b & $\begin{array}{l}\text { Expression vector designed for the purification of proteins, introduces a } \\
10 \text {-His-tag at N-terminus of protein, Amp }\end{array}$ & Novagen \\
\hline pRBL & pTRC99A containing gene for T4 DNA ligase, Amp & Ren et al., 1997 \\
\hline pRJ345 & pTRC99A expressing the colicin immunity protein $\operatorname{Im} 9$, Amp & Wallis et al., 1995 \\
\hline pRB20 & pET-16b expressing full-length E. coli ligA (including 10-His-tag), Amp & Wilkinson et al., 2003 \\
\hline
\end{tabular}


Cloning of DNA ligases. Genomic DNAs were prepared from appropriate overnight cultures using a Wizard Genomic DNA purification kit (Promega). Cloning of E. coli K-12 $\mathrm{NAD}^{+}$-DNA ligase (LigA; 671 amino acids) has been described previously (Wilkinson et al., 2003). LigA from E. coli GR501 (LigA251) was prepared in a similar manner: amplified from genomic DNA isolated from E. coli GR501 by PCR with a proof-reading DNA polymerase. Note that the $5^{\prime}$ primer contained an NdeI site and that the $3^{\prime}$ primer contained a BamHI site. PCR products were cloned using the Zero Blunt TOPO Cloning kit (Invitrogen) and sequenced to confirm that the recombinant gene was the same as that identified in E. coli GR501 genomic DNA. Fragments were excised from the TOPO vectors using the NdeI and BamHI sites and cloned into pET16b (Novagen). Proteins overexpressed from this vector contain a $10-\mathrm{His}$ tag within an extra 21 amino acids $(2 \cdot 5 \mathrm{kDa})$ at the $\mathrm{N}$-terminus.

To allow overexpression of proteins in E. coli GR501, full-length ligases plus the His-tag were excised from pET-16b vectors using the NcoI and BamHI sites and cloned into pTRC99A (Amersham Pharmacia). In control experiments analysing expression of proteins from pTRC99A, T4 DNA ligase was expressed from pRBL (Ren et al., 1997) and Im9, an inhibitor of the colicin E9, was expressed from pRJ354 (Wallis et al., 1995).

Protein purification. For protein expression, all E. coli cultures were grown at $37^{\circ} \mathrm{C}$ in LB containing ampicillin and chloramphenicol. The pET16b derivatives were transformed into E. coli BL21 (DES) pLysS, and cells were plated on LB agar containing antibiotics and grown overnight. Single colonies were inoculated into $5 \mathrm{ml}$ liquid medium, grown overnight and diluted 100 -fold into fresh medium $(50-500 \mathrm{ml})$. After growth to mid-exponential phase $\left(\mathrm{OD}_{600}=0 \cdot 4\right.$ $0 \cdot 6)$, protein expression was induced by addition of IPTG to $0.4 \mathrm{mM}$. After $4 \mathrm{~h}$ further incubation, cells were harvested, sonicated and centrifuged to separate soluble and insoluble fractions. DNA ligases were purified from the soluble fraction using columns with affinity for the His-tag (HiTrap Chelating HP, Amersham Pharmacia). After concentration using Vivaspin $20 \mathrm{ml}$ concentrators with a 5000 molecular weight cut-off PES membrane, the samples were loaded on to a HiLoad 16/60 Superdex 75 prep grade column. The column was run at $1 \mathrm{ml} \mathrm{min} \mathrm{min}^{-1}$ for $2 \mathrm{~h}$ in $20 \mathrm{mM}$ Tris, $\mathrm{pH} 7 \cdot 5$, $200 \mathrm{mM} \mathrm{NaCl}$. The $\mathrm{OD}_{280}$ was measured to find the peak fractions, which were collected, pooled and concentrated. Typically, full-length DNA ligases eluted after $45 \mathrm{~min}$. Protein concentrations were determined by the Bradford method (Bio-Rad Protein Assay). In general, lower levels of expression were obtained for LigA251 than for LigA: standard amounts of pure protein obtained from each litre of induced culture were $100 \mathrm{mg}$ for LigA and $15 \mathrm{mg}$ for LigA251. The thermal stability of LigA and LigA251 was analysed by SDS-PAGE after incubation of $2 \mu \mathrm{g}(30 \mathrm{pmol})$ of protein at temperatures between 4 and $37^{\circ} \mathrm{C}$ for $21 \mathrm{~h}$. For long-term storage at $-80^{\circ} \mathrm{C}$, glycerol was added to a final concentration of $20 \%(\mathrm{v} / \mathrm{v})$.

Analysis of ligation activity. In vitro assays of ligation activity were performed using a double-stranded $40 \mathrm{bp}$ DNA substrate carrying a single-strand nick between bases 18 and 19 (Timson \& Wigley, 1999). This substrate was created in TBE buffer by annealing an 18-mer (5'-GTA AAA CGA CGG CCA GTG-3') and a 22-mer ( $5^{\prime}$-AAT TCG AGC TCG GTA CCC GGG G-3') to a complementary 40-mer (5'-CCC CGG GTA CCG AGC TCG AAT TCA CTG GCC GTC GTT TTA C- $\left.3^{\prime}\right)$. At the $5^{\prime}$ end, the 18 -mer contained a fluorescein molecule and the 22-mer was phosphorylated.

The nicked $40 \mathrm{bp}$ substrate was used to assay the in vitro ligation activity of each enzyme. Time-course assays used 750 pmol DNA in $50 \mu \mathrm{l}$ reactions and different amounts of LigA and LigA251, and were performed at various temperatures and times. Reactions were conducted in the presence of $26 \mu \mathrm{M} \mathrm{NAD}^{+}$in $30 \mathrm{mM}$ Tris, $\mathrm{pH} 8 \cdot 0$, $4 \mathrm{mM} \mathrm{MgCl}_{2}, 1 \mathrm{mM}$ DTT and $50 \mu \mathrm{g} \mathrm{BSA} \mathrm{ml}{ }^{-1}$. At the end of the incubation, $5 \mu \mathrm{l}$ samples were mixed with an equal volume of formamide loading buffer, heated to $95^{\circ} \mathrm{C}$, loaded onto a $15 \%$ polyacrylamide/urea gel $(10 \times 10 \mathrm{~cm})$ and run at $300 \mathrm{~V}$ for $1 \mathrm{~h}$ in $1 \times$ TBE. Reaction products on the gel were visualized and quantified using a Molecular Dynamics Storm phosphorimager.

To assay for ligation activity in vivo, we tested whether different plasmid constructs could complement E. coli GR501 at temperatures that are normally restrictive to growth. Following the guidelines for the use of E. coli GR501, cells were transformed with pTRC99A containing the gene for the relevant DNA ligase and grown on LB agar containing ampicillin at $30^{\circ} \mathrm{C}$ or $43^{\circ} \mathrm{C}$.

Analysis of LigA expression. Bacterial cultures were grown at the required temperature and, at exactly $\mathrm{OD}_{600}=0 \cdot 7,5 \mathrm{ml}$ of culture was harvested and resuspended in $100 \mu \mathrm{l}$ Tris/glycine SDS gel loading buffer (Sambrook \& Russell, 2001). In some experiments, $0 \cdot 4 \mathrm{mM}$ IPTG was added at $\mathrm{OD}_{600}=0 \cdot 2$ to induce overexpression of recombinant DNA ligases. Cell extracts were fractionated by SDSPAGE, and LigA and LigA251 were detected by a standard protocol for Western blotting (Western Blue Express, Promega). Adenylated and deadenylated forms of LigA were resolved by electrophoresis at $100 \mathrm{~V}$ for $5 \mathrm{~h}$ on $15 \%$ SDS-PAGE, whilst detection of His-tagged proteins was performed after electrophoresis at $150 \mathrm{~V}$ for $1 \mathrm{~h}$ on $8 \%$ SDS-PAGE. The primary antibody to E. coli LigA (Davids Biotechnologie) was a rabbit polyclonal raised against purified LigA (containing His-tag), and the primary antibody to the His-tag was a mouse monoclonal (Amersham Pharmacia). Appropriate secondary antibodies were conjugated to alkaline phosphatase (Promega).

Sequence analysis and molecular modelling. Sequences of DNA ligases were identified from the NCBI database (http://www.ncbi.nlm. nih.gov/). Alignment of protein sequences was performed using the CLUSTAL W method (DNAStar LaserGene MegAlign). A molecular model for E. coli LigA was generated using the X-ray crystallographic structure of Thermus filiformis $\mathrm{NAD}^{+}$-DNA ligase (Lee et al., 2000) (Protein Database accession number 1DGT). The structure was automatically generated using SwISS-MODEL (http://www.expasy.ch/spdbv/) (Guex \& Peitsch, 1997) and visualized using RasMol. Since the structure of $T$. filiformis DNA ligase does not contain high-resolution details of all amino acids (Lee et al., 2000), only amino acids 1-586 are contained in our molecular model of E. coli LigA.

\section{RESULTS}

\section{Growth analysis of E. coli GR501}

Studies of the essential functions of LigA have been aided by several E. coli strains that carry temperature-sensitive (ts) mutations. Although many of these strains were isolated by the late 1970s, details about the genetic and biochemical basis of these ts mutations are incomplete. E. coli GR501 is viable at $30^{\circ} \mathrm{C}$, but is unable to grow at temperatures of $42^{\circ} \mathrm{C}$ and above (Dermody et al., 1979). Since this strain is becoming particularly useful for searches of potential inhibitors of $\mathrm{NAD}^{+}$-DNA ligases (Brotz-Oesterhelt et al., 2003), it is imperative that the genetic and biochemical basis of the ts mutation is identified. Note that the DNA ligase gene in E. coli GR501 is the ligA251 allele derived from E. coli SG251 (Dermody et al., 1979); we refer to the protein product of this gene as LigA251.

E. coli GR501 was obtained from the E. coli Genetic Stock Center (CGSC). To confirm that this strain had a 
temperature-sensitive mutation in $\operatorname{lig} A$, we tested for complementation of the strain with functional DNA ligases expressed from pTRC99A, which can be used to express genes in E. coli under the control of an IPTG-inducible strong promoter (Ren et al., 1997). Previous studies have confirmed that expression of DNA ligases from this vector allows growth of E. coli GR501 at temperatures that are normally non-permissive (Brotz-Oesterhelt et al., 2003; Kodama et al., 1991; Ren et al., 1997; Wilkinson et al., 2003). Two controls were performed to confirm that complementation of growth at non-permissive temperatures was due to the expression of DNA ligases which are functional in E. coli GR501. Firstly, the thermosensitivity of cells harbouring the empty vector (pTRC99A) was assessed. Secondly, to confirm that the complementation was not due to non-specific protein expression, bacteria were transformed with pRJ345 (Wallis et al., 1995), a pTRC99Aderived plasmid which expresses the colicin inhibitor Im9 and has no DNA ligase functions. E. coli GR501 strains harbouring these derivatives of pTRC99A were grown on plates at 30 or $43^{\circ} \mathrm{C}$. This assay was carried out without IPTG, as it had been shown that the vector expression system allowed a high level of protein synthesis even in the absence of the inducer (see below). As expected, growth was observed at $30^{\circ} \mathrm{C}$ (Fig. 1a). However, cells lacking a wild-type DNA ligase grew more slowly than cells encoding such an enzyme from the vector. In contrast, only plasmids expressing E. coli LigA and T4 DNA ligase complemented the temperature-sensitive mutation and allowed E. coli GR501 to grow well on plates at $43^{\circ} \mathrm{C}$. Note that these observations confirm that mutations in the $\mathrm{NAD}^{+}$DNA ligase of E. coli can be complemented by overexpression of an ATP-DNA ligase (Doherty et al., 1996; Kodama et al., 1991).

To further assess the efficiency of complementation of E. coli GR501 by the recombinant DNA ligases, we compared strain viability at 30 and $43{ }^{\circ} \mathrm{C}$ on plates (Table 2). The effect of the ligA251 allele was examined by comparison of growth with E. coli CHE30, which is isogenic to E. coli GR501 apart from the ts mutation (Dermody et al., 1979). Generally, from each strain grown from a stationaryphase culture there were at least $10^{9}$ c.f.u. $\mathrm{ml}^{-1}$ at $30^{\circ} \mathrm{C}$ (Table 2), as expected for E. coli in good conditions for growth. Thus, overexpression of the T4 or E. coli DNA ligase had no significant effect on cell viability at $30^{\circ} \mathrm{C}$. (a)

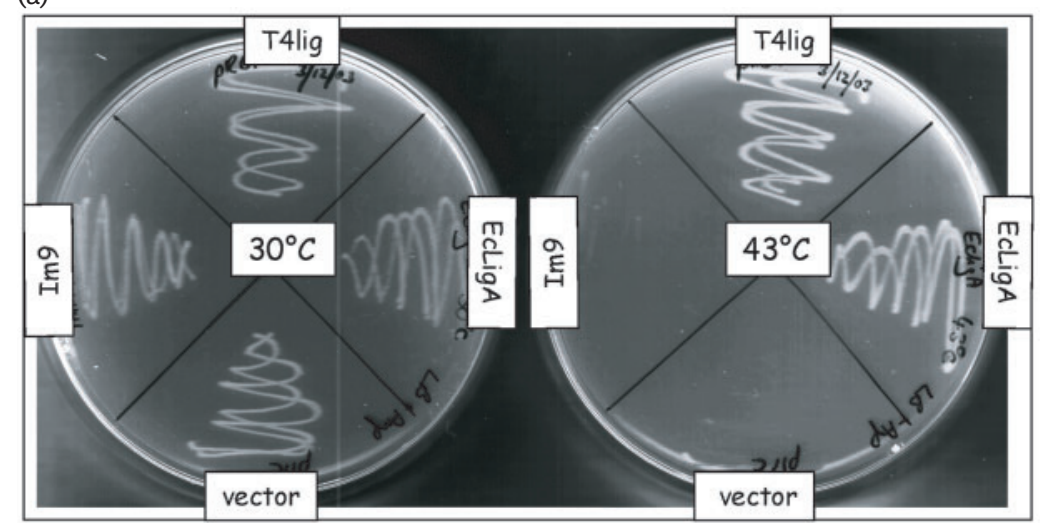

(b)

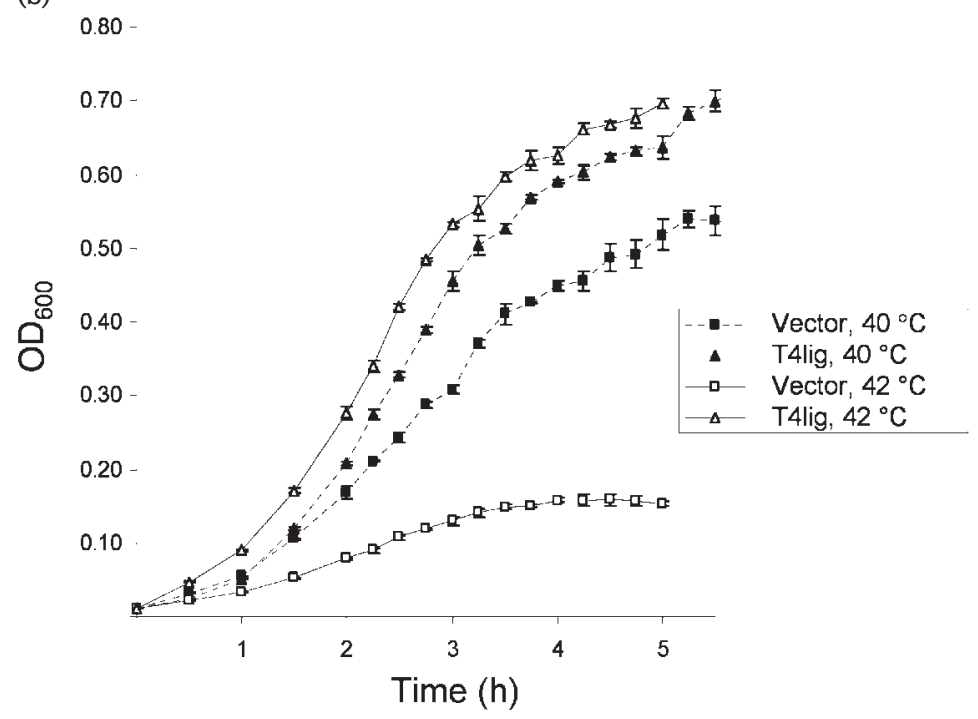

Fig. 1. Growth analysis and complementation of E. coli GR501. (a) E. coli GR501 transformed with vector pTRC99A expressing various proteins was streaked onto LB agar plates containing ampicillin and grown at $30^{\circ} \mathrm{C}$ (left-hand plate) or $43^{\circ} \mathrm{C}$ (righthand plate). (b) Growth curves of E. coli GR501 with or without expression of T4 DNA ligase at 40 and $42{ }^{\circ} \mathrm{C}$. Data represent the mean and SE of three experiments under the growth conditions indicated. 'Vector' and 'T4lig' refer to $E$. coli GR501 containing pTRC99A and pRBL, respectively. 
Table 2. Strain viability at $30^{\circ} \mathrm{C}$ and $43^{\circ} \mathrm{C}$

The left-hand column provides the plasmid name and its expressed protein product (see Table 1). Viability is expressed as the number of colony forming units per $\mathrm{ml}\left(\times 10^{9}\right)$ of the original culture. Results represent the mean $\pm \mathrm{SD}$ of three independent experiments.

\begin{tabular}{|lcc|}
\hline \multirow{2}{*}{. coli strain and plasmid } & \multicolumn{2}{c|}{ Viability at: } \\
\cline { 2 - 3 } & $\mathbf{3 0}{ }^{\circ} \mathbf{C}$ & $\mathbf{4 3}{ }^{\circ} \mathbf{C}$ \\
\hline GR501 & $6 \cdot 48 \pm 0 \cdot 98$ & $<0 \cdot 005$ \\
GR501 + pTRC99A (vector alone) & $3 \cdot 06 \pm 0 \cdot 83$ & $<0 \cdot 005$ \\
GR501 + pRBL (T4lig) & $7 \cdot 13 \pm 1 \cdot 01$ & $4 \cdot 54 \pm 1 \cdot 45$ \\
GR501 + pRB154 (E. coli LigA) & $6 \cdot 73 \pm 0 \cdot 15$ & $5 \cdot 36 \pm 0 \cdot 90$ \\
GR501 + pRB159 (E. coli LigA251) & $5 \cdot 36 \pm 1 \cdot 13$ & $4 \cdot 12 \pm 1 \cdot 04$ \\
CHE30 & $5 \cdot 14 \pm 0 \cdot 76$ & $2 \cdot 67 \pm 0 \cdot 96$ \\
CHE30 + pTRC99A (vector alone) & $3 \cdot 08 \pm 0 \cdot 66$ & $0 \cdot 95 \pm 0 \cdot 32$ \\
CHE30 + pRBL (T4lig) & $4 \cdot 27 \pm 1 \cdot 33$ & $0 \cdot 74 \pm 0 \cdot 25$ \\
CHE30 + pRB154 (E. coli LigA) & $4 \cdot 10 \pm 1 \cdot 15$ & $1 \cdot 34 \pm 0 \cdot 36$ \\
CHE30 + pRB159 (E. coli LigA251) & $4 \cdot 48 \pm 1 \cdot 82$ & $1 \cdot 46 \pm 1 \cdot 21$ \\
\hline
\end{tabular}

Viable counts at $43^{\circ} \mathrm{C}$ revealed the weak viability of E. coli GR501 alone or with the expression vector pTRC99A, and the good viability of the isogenic strains encoding the T4 or E. coli DNA ligase. Expression of recombinant DNA ligase had a small effect on the viability of the wild-type strain E. coli CHE30. This effect was observed consistently in independent experiments, although the cause was not clear. These experiments show that expression of recombinant DNA ligases restores the viability of E. coli GR501 to wild-type levels.

To better determine the ts phenotype of ligA251, growth of E. coli GR501 with or without expression of T4 DNA ligase was followed in liquid culture at various temperatures. At 30,37 and $40^{\circ} \mathrm{C}$, both strains grew similarly, indicating that E. coli GR501 did not require expression of an additional wild-type DNA ligase at temperatures up to $40^{\circ} \mathrm{C}$ (Fig. $1 \mathrm{~b}$ and data not shown). At $42^{\circ} \mathrm{C}$, growth was dramatically reduced in the absence of the T4 DNA ligase, but not in its presence (Fig. 1b). Suppression of the growth defect was also observed with E. coli GR501 cells expressing E. coli LigA from pTRC99A (Fig. 5). Like most strains of E. coli, at $44{ }^{\circ} \mathrm{C}$ E. coli GR501 did not grow well in liquid culture even with expression of T4 DNA ligase from pRBL (data not shown). These experiments on solid and in liquid media confirm that E. coli GR501 carries a ts mutation that can be complemented by expression of a functional DNA ligase.

\section{Identification of the mutation in E. coli GR501}

Temperature-sensitive phenotypes can be caused by different phenomena, including altered expression or function of a protein. To determine if the ts mutation of E. coli GR501 was due to reduced expression of LigA251, we analysed the amount of protein present in cell extracts prepared from

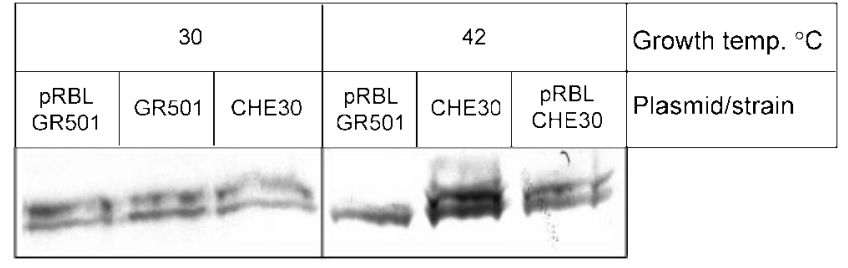

Fig. 2. Western blot analysis of ligase expression from E. coli GR501. E. coli GR501 and CHE30, with or without expression of the T4 ligase from $\mathrm{pRBL}$, were grown at 30 and $42{ }^{\circ} \mathrm{C}$. Total protein samples from cultures grown to $\mathrm{OD}_{600}=0.7$ were separated by $15 \%$ SDS-PAGE and transferred to a nitrocellulose membrane. The ligase expressed from the E. coli chromosome was detected using a polyclonal antibody. The upper and lower bands are likely to indicate the adenylated and nonadenylated forms of LigA, respectively.

cultures grown at permissive and non-permissive temperatures. Previously, we had prepared a rabbit polyclonal antibody to E. coli K-12 LigA (Wilkinson et al., 2003) which showed cross-reactivity to LigA251 from E. coli GR501. As a positive control for wild-type ligA, we used E. coli CHE30 (Dermody et al., 1979). Bacterial cultures were grown at various temperatures to $\mathrm{OD}_{600}=0 \cdot 7$, and equal quantities of cells were analysed by SDS-PAGE and Western blotting using the antibody to E. coli LigA (Fig. 2). In these experiments we detected two forms of LigA with slightly altered mobility during PAGE. These two forms have been shown to be equivalent to adenylated and non-adenylated protein for several DNA ligases, including that from Thermus thermophilus (Barany \& Gelfand, 1991). Note that adenylated LigA migrates more slowly (equivalent to higher molecular mass). At $30^{\circ} \mathrm{C}$, the level of expression of DNA ligase was similar in E. coli GR501 and E. coli CHE30, with approximately equal amounts of adenylated and nonadenylated enzyme. Thus, the ts mutation does not alter the level of expression of LigA251 under conditions where the strain is normally viable.

In liquid culture, we showed that $42^{\circ} \mathrm{C}$ was the optimal temperature for detecting complementation of E. coli GR501 by T4 DNA ligase (see above). To assess expression of the chromosomal form of LigA251 at $42{ }^{\circ} \mathrm{C}$ (where E. coli GR501 is normally non-viable), we analysed cells complemented with T4 DNA ligase. The T4 enzyme did not crossreact with the antibody to E. coli LigA (data not shown), and in any case had a different mobility to that of LigA on SDS-PAGE. Inclusion of pRBL, which expresses T4 DNA ligase, did not significantly affect the expression of the ligase in E. coli GR501 at $30^{\circ} \mathrm{C}$ or E. coli CHE30 at $42^{\circ} \mathrm{C}$ (Fig. 2). Furthermore, the Western blot analysis showed no major changes in ligase concentration in any of the strains grown at 30 and $42{ }^{\circ} \mathrm{C}$ (Fig. 2). However, this analysis showed that, for E. coli GR501 at $42^{\circ} \mathrm{C}$, most LigA251 was present in a non-adenylated form. These data suggest that, although LigA251 is expressed in E. coli GR501 
at all temperatures monitored, at the higher temperatures most of the protein is non-adenylated and is therefore not competent for DNA end-joining. Thus, at non-permissive temperatures, the ts mutation has no major effect on the level of expression of DNA ligase, but reduces the level of active adenylated enzyme.

Since these data suggest that LigA251 is expressed at $42{ }^{\circ} \mathrm{C}$ in E. coli GR501, we assessed whether the sequence of the protein could explain the ts mutation. Genomic DNA was prepared from E. coli GR501, and sequencing of its ligA251 revealed a single base substitution, compared to lig $A$ in E. coli $\mathrm{K}-12$, of cytosine to thymine at base pair 43 . This mutation results in a change from Leu to Phe at position 15 of the protein (Fig. 3). Although this residue is not absolutely conserved in all $\mathrm{NAD}^{+}$-DNA ligases, it is always a hydrophobic amino acid. In the $\mathrm{NAD}^{+}$-DNA ligases, this amino acid resides within the bi-helix that is close to the N-terminus. Since this region of LigA is important for binding of $\mathrm{NAD}^{+}$(Sriskanda \& Shuman, 2002), the ts mutation in E. coli GR501 is likely to affect binding of $\mathrm{NAD}^{+}$and the subsequent adenylation of LigA.

\section{Biochemical analysis of LigA from $E$. coli GR501}

Previously, we have purified an active recombinant form of LigA from E. coli K-12 with a 10-His-tag at the N-terminus (Wilkinson et al., 2003). Using a similar strategy, ligA251 from E. coli GR501 was amplified from genomic DNA using a proof-reading polymerase and cloned into the expression vector pET-16b. DNA sequencing confirmed that the only mutation in the cloned gene was the cytosine to thymine transition at base pair 43 , which produces a change from Leu to Phe at amino acid 15 of the protein. The protein product (LigA251) was overexpressed and purified by affinity chromatography, with further purification by gelfiltration chromatography. Analysis by SDS-PAGE detected no proteins other than full-length DNA ligase (data not shown).

In vitro analysis of purified protein was used to test whether or not the ts phenotype of E. coli GR501 was due to reduced protein stability at higher temperatures. SDSPAGE was used to analyse if there was a difference in the
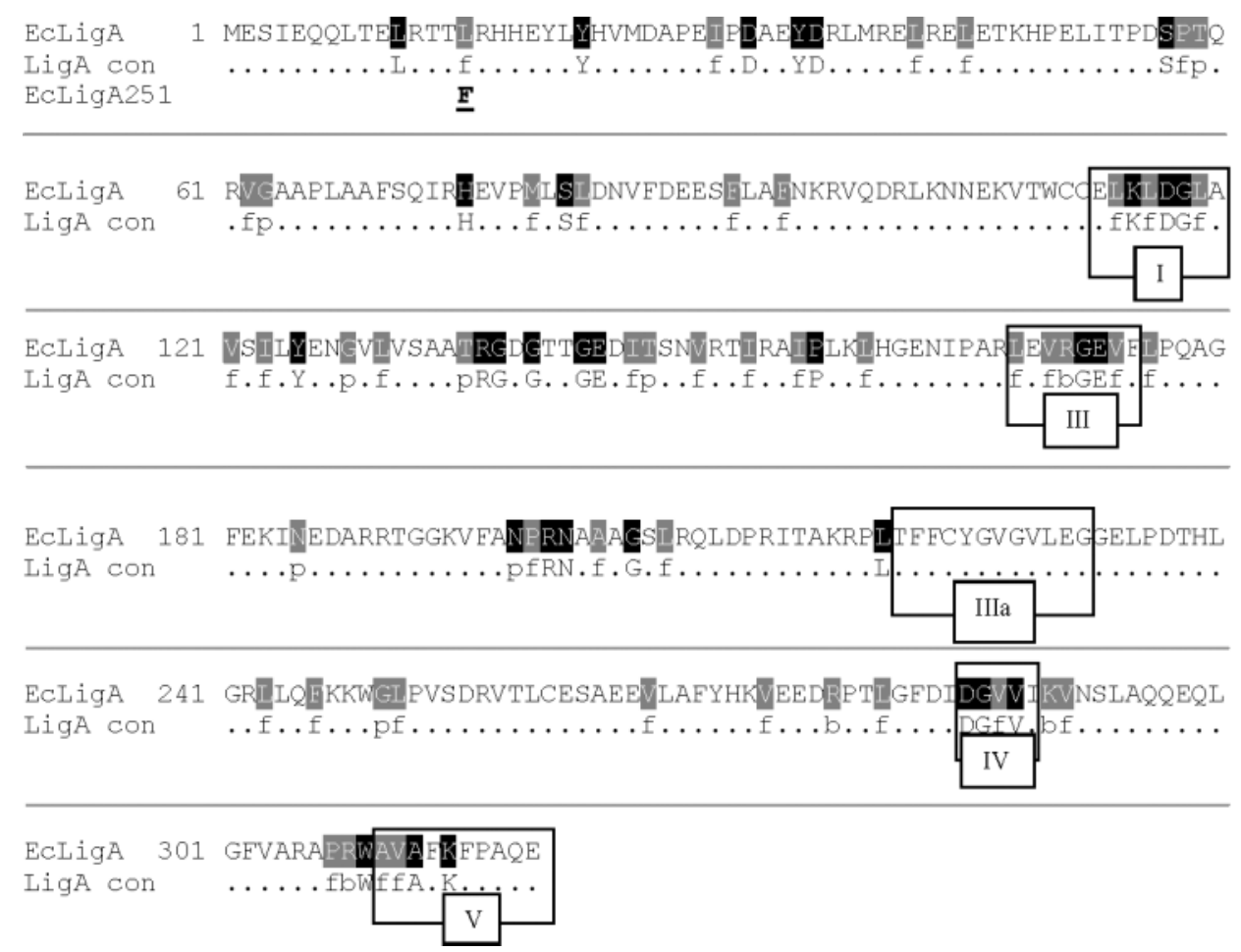

Fig. 3. Amino acid sequence of LigA251. The sequence shows only the first 319 amino acids (out of 671 ) of $E$. coli LigA and the mutation identified in LigA251 (Leu to Phe at amino acid 15). All other residues are identical in LigA and LigA251. Boxes indicate five sequence motifs (motifs I, III, IIla, IV and V) conserved in DNA ligases and mRNA capping enzymes (Wilkinson et al., 2001). On the E. coli LigA sequence, highlighting indicates residues which are identical (black) or have similar functionality (grey) in more than $90 \%$ of $\mathrm{NAD}^{+}$-dependent DNA ligase sequences in the $\mathrm{NCBI}$ database. For this set of $\mathrm{NCBI}$ sequences, 'LigA con' shows the identical amino acids (capitals) and conserved functional groups (lower case). Standard functional groups of amino acids are used as follows: a (acidic) =DE; b (basic)=HKR; $f$ (hydrophobic) = A, F, I, L, M, P, V, W; $\mathrm{p}($ polar) $=\mathrm{C}, \mathrm{G}, \mathrm{N}, \mathrm{Q}, \mathrm{S}, \mathrm{T}, \mathrm{Y}$. 


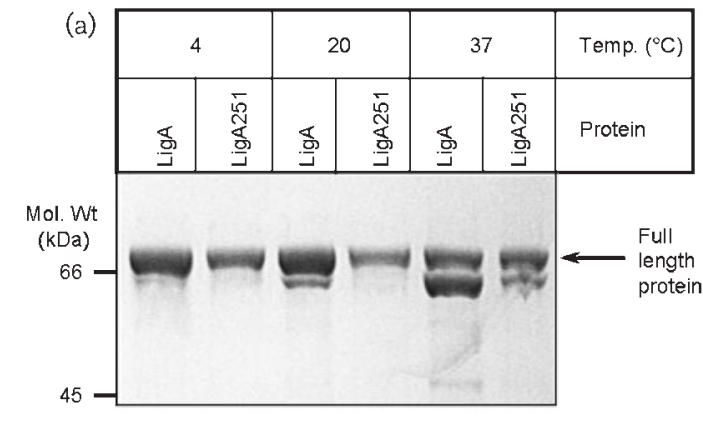

(b)

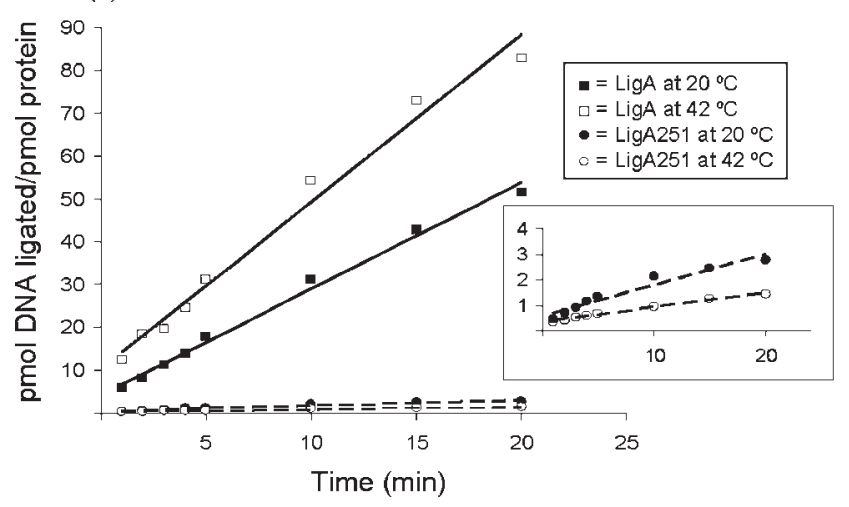

Fig. 4. In vitro analysis of LigA251 activity. (a) Approximately $30 \mathrm{pmol}$ of recombinant LigA251 or LigA were incubated for $21 \mathrm{~h}$ at the temperatures indicated. Samples were analysed by $10 \%$ SDS-PAGE and protein was detected by Coomassie Brilliant Blue staining. Sizes $(\mathrm{kDa})$ are shown for molecular weight markers included on the same gel. (b) In vitro ligation assays with recombinant LigA251 or LigA were performed for various times at $20^{\circ} \mathrm{C}$ (filled symbols) or $42{ }^{\circ} \mathrm{C}$ (open symbols). DNA substrate $(750 \mathrm{pmol})$ was incubated with $1.6 \mathrm{pmol}$ LigA or 70 pmol LigA251. Data are plotted as the extent of cumulative ligation over time. Reactions with LigA251 are indicated by circles (dashed line) and reactions with LigA are indicated by squares (solid line). Data are the mean of two experiments and the standard error was within the symbol area. To allow improved evaluation of reactions with LigA251, the inset shows the same data on an expanded $y$ axis.

stability of wild-type and ts LigA when incubated at different temperatures for extended periods. Some fragmentation of proteins was observed during extended incubation (21 h) at $42^{\circ} \mathrm{C}$, but the effects were no worse for LigA251 than for LigA (Fig. 4a). Thus, in vitro analysis suggests that the mutation does not decrease the overall stability of the protein at high temperature.

For cell extracts from an E. coli strain with the same ts mutation as GR501, it was observed that DNA end-joining activity was reduced by almost 500 -fold at $40{ }^{\circ} \mathrm{C}$ compared to $25^{\circ} \mathrm{C}$ (Dermody et al., 1979). By contrast, there was little difference in the DNA ligation activity of an isogenic wild-type strain at these two temperatures. We wished to analyse whether a similar relationship in DNA ligation activity occurred in our recombinant proteins. DNA ligase activity of LigA251 and LigA was analysed using a standard in vitro assay for DNA ligation (Timson \& Wigley, 1999; Wilkinson et al., 2003). To compare the DNA ligase activity of LigA251 with that of LigA, we performed time-course reactions at different temperatures (Fig. 4b). The rate of DNA nick ligation by wild-type LigA was approximately $5 \mathrm{~mol}$ per mol protein per min at $20^{\circ} \mathrm{C}$. This rate is comparable to that reported for other recombinant $\mathrm{NAD}^{+}$DNA ligases (e.g. see Kaczmarek et al., 2001; Sriskanda \& Shuman, 2002; Tong et al., 2000). At $20^{\circ} \mathrm{C}$, the rate of DNA ligation by LigA251 was about 20 -fold lower than that of LigA. Raising the temperature to $42^{\circ} \mathrm{C}$ increased slightly the activity of LigA, but the activity of LigA 251 decreased; at this temperature, the difference in rate of ligation between LigA251 and LigA was about 60-fold. These observations are in broad agreement with earlier measurements of the effects of ts mutations on DNA ligation activity in cell extracts (Dermody et al., 1979; Lehman, 1974), though the difference is more pronounced with crude extracts.

\section{Effect of overexpression of LigA251 on E. coli GR501 viability}

The above data show that LigA251 retained low levels of DNA ligation activity at $42{ }^{\circ} \mathrm{C}$ (Fig. 4). Since the nonviability of cultures at higher temperatures is likely to be due to insufficient DNA end-joining activity, we reasoned that overexpression of LigA251 might complement and allow growth of the ts strain. Following procedures outlined above for other DNA ligases, LigA251 was cloned into pTRC99A and transformed into E. coli GR501. These bacteria were able to grow well on plates lacking IPTG at $42{ }^{\circ} \mathrm{C}$ (Table 2), indicating that overexpression of LigA251 from pTRC99A could complement the ts mutation. To confirm this observation, E. coli GR501 overexpressing either LigA or LigA251 was grown in liquid culture at various temperatures. In all cases, complementation of E. coli GR501 by expression of LigA251 or LigA resulted in similar growth patterns, as indicated at 40 and $42{ }^{\circ} \mathrm{C}$ in Fig. 5a. Thus, overexpression of LigA251 was able to overcome the growth problems that normally result from the reduced activity of this mutated LigA. Levels of expression of the recombinant proteins at $42{ }^{\circ} \mathrm{C}$ were analysed by Western blot using a primary antibody to the His-tag (Fig. 5b). Similar levels of expression were observed at $30{ }^{\circ} \mathrm{C}$ (data not shown). Note that significant levels of recombinant protein were detected in the absence of IPTG, indicating that expression from the strong promoter of pTRC99A was not effectively inhibited in E. coli GR501. There was some regulation at the lac-based promoter, since addition of $0.4 \mathrm{mM}$ IPTG increased expression of the recombinant proteins by a further five to tenfold (Fig. 5b). Comparison with known amounts of purified recombinant LigA allowed estimation of the expression levels of LigA251 from the chromosome of E. coli GR501 and from pTRC99A in the absence of IPTG (data not shown). This analysis identified that the amount of DNA ligase expressed from 


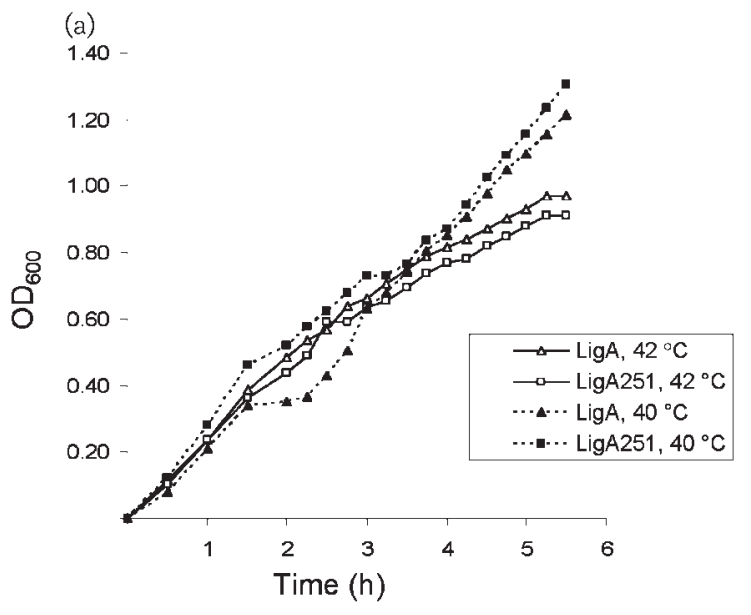

(b)

\begin{tabular}{|c|c|c|c|l|}
\hline \multicolumn{2}{|c|}{ LigA251 } & \multicolumn{2}{|c|}{ LigA } & Protein expressed \\
\hline- & + & - & + & IPTG included \\
\hline & & & \multirow{2}{*}{$\begin{array}{l}\text { Recombinant } \\
\text { LigA }\end{array}$} \\
\hline
\end{tabular}

Fig. 5. Growth complementation of E. coli GR501 by increased expression of its host DNA ligase. (a) E. coli GR501 expressing E. coli LigA or LigA251 was grown at 40 or $42{ }^{\circ} \mathrm{C}$ in LB containing ampicillin. (b) $E$. coli GR501 expressing $E$. coli LigA or LigA251 was grown at $42{ }^{\circ} \mathrm{C}$. In some cases, $0.4 \mathrm{mM}$ IPTG was added at $\mathrm{OD}_{600}=0.2$. Total protein samples from cultures grown to $\mathrm{OD}_{600}=0.7$ were separated on $8 \%$ SDS-PAGE and transferred to a nitrocellulose membrane. Recombinant LigA was detected using a monoclonal antibody to the His-tag. Note that these electrophoresis conditions did not resolve the adenylated and non-adenylated forms of LigA.

the vector pTRC99A was 20- to 50-fold higher than that expressed from the chromosomal gene.

\section{DISCUSSION}

$\mathrm{NAD}^{+}$-DNA ligase (LigA) is an essential enzyme in E. coli, and it is likely that homologous proteins are essential for all bacteria (Wilkinson et al., 2001). Bacterial strains with temperature-sensitive (ts) mutations in such essential genes are required to study their role(s) in vivo. Several ts strains of $E$. coli are thought to have mutations in ligA (Dermody et al., 1979; Gellert \& Bullock, 1970; Karam et al., 1979; Konrad et al., 1973; Modrich \& Lehman, 1971). Although such strains have been available for many years, their mutations have not been well characterized at the molecular level. Using in vitro and in vivo experiments, we have filled this gap for E. coli GR501 and have determined the mutation leading to its ts activity.

E. coli GR501 is one of the most ligase-deficient strains identified, and the ts phenotype is a consequence of problems with the completion of DNA replication at elevated temperature (Dermody et al., 1979). The mutation can be complemented by a variety of DNA ligases, indicating that the ts mutation is related to the function of $E$. coli ligA. Interestingly, the strain can be complemented by both $\mathrm{NAD}^{+}$- and ATP-DNA ligases (Brotz-Oesterhelt et al., 2003; Doherty et al., 1996; Kodama et al., 1991; Wilkinson et al., 2003). This reinforces the conclusion that the mutation is related to effects on replication, and supports the use of this strain in studies that aim to identify inhibitors that are specific to the $\mathrm{NAD}^{+}$-versions of the DNA ligases (Brotz-Oesterhelt et al., 2003).

Temperature-sensitive strains contain conditional-lethal mutations: they result in lethality under restrictive conditions, but retain normal function under permissive conditions. Such ts mutations can arise via different processes, producing effects at the level of expression or activity of the ts gene at the non-permissive temperature. We have confirmed that LigA251 is expressed at similar levels at all temperatures tested. In vitro ligation assays have confirmed that the ts DNA ligase is active, but has reduced activity, at higher temperatures. Compared to wild-type LigA, LigA251 has reduced activity at all temperatures, but the difference in activity is exaggerated at temperatures that are non-permissive for growth.

These observations suggest that E. coli GR501 is temperature sensitive because its DNA ligase activity is insufficient to sustain growth at non-permissive temperatures. Our observed 60-fold difference in the rates of ligation by LigA and LigA251 at $42{ }^{\circ} \mathrm{C}$ is less than the effect of ts mutations on the DNA ligation activity of E. coli cell extracts (Dermody et al., 1979; Lehman, 1974). These differences may indicate that another cofactor influences the ligation activity of crude extracts, or they may reflect limitations in the accuracy of the different assays of DNA ligation. Interestingly, we observed that a 20 - to 50 -fold overexpression of LigA251 overcomes the ts phenotype, which is in reasonable agreement with the effect of the mutation on the in vitro ligation activity of the protein at $42^{\circ} \mathrm{C}$. However, moving from 30 to $42^{\circ} \mathrm{C}$ has only a small effect on the activity of LigA251, and it is unlikely that this is sufficient to explain the pronounced consequences for viability. Rather, the overall effect is likely due to a combination of factors affecting the bacteria. Although E. coli GR501 has good viability at temperatures up to $40{ }^{\circ} \mathrm{C}$, it grows quite slowly on LB agar plates, suggesting that the growth rate of the ts strain may be compromised even at low temperatures. Switching growth to higher temperatures applies additional stresses to the bacteria, which may mean that DNA ligase has a more important role to play due to the fact that more replication forks are likely to be active, or perhaps the enzyme is required to carry out more DNA repair events. Thus, the relatively small change in biochemical activity of the mutated DNA ligase may be linked to a large physiological effect.

For E. coli GR501, the level of adenylated LigA251 appeared to be reduced at $42^{\circ} \mathrm{C}$ compared to $30^{\circ} \mathrm{C}$ and 
also in comparison to wild-type strains at the same temperature. Preliminary in vitro experiments confirmed that LigA251 was less readily adenylated by $\mathrm{NAD}^{+}$than LigA (unpublished data). A thorough in vitro biochemical analysis is required to understand the full implications of the ts mutation on the reaction mechanism.

Sequencing of genomic and cloned DNA established that the mutation in ligA251 of E. coli GR501 is a cytosine to thymine transition at base 43 , which leads to the substitution of Phe for Leu at residue 15 of the protein (LigA251). The effects of mutations in this position of E. coli LigA have not been studied before, but the Nterminal 38 residues are required for adenylation of the protein (Sriskanda et al., 1999). Amino acids in the homologous position to Leu15 are conserved as hydrophobic residues in all $\mathrm{NAD}^{+}$-DNA ligases (Fig. 3), suggesting that it has an important function. The fact that both Leu and Phe are hydrophobic may explain why LigA251 retains some DNA ligase activity. However, the introduction of this change clearly has some effect on protein activity. To aid evaluation of the effect of this mutation on LigA function, we used the X-ray crystallographic structure of LigA from Thermus filiformis (Lee et al., 2000) to generate a molecular model of E. coli LigA. Fig. 6 shows the backbone structure of the molecular model, with highlighting of the side-chains of Leu15

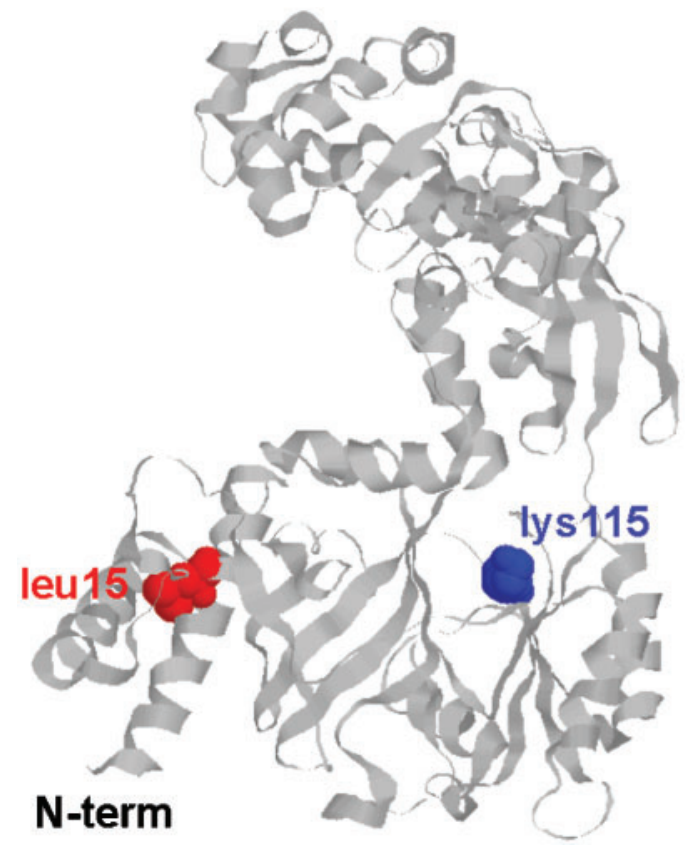

Fig. 6. Putative molecular structure of $E$. coli DNA ligase. A molecular model covering amino acids 1-586 of $E$. coli LigA was generated by the SWISS-MODEL program based on the crystallographic structure of the T. filiformis ligase and the polypeptide backbone was visualized using RasMol. Residues highlighted in blue and red indicate the active site lysine (Lys115) and the site of mutation in LigA251 (Leu15), respectively. and the active site lysine (Lys115). Clearly, no direct interactions between Leu15 and the active site are predicted from this model. The main difference in the structure of Leu and Phe is the bulky benzene ring in the side chain of Phe. Although the relationship of the amino acid mutation to enzymic activity or structure has not been directly demonstrated at this time, the molecular model suggests that the alteration of amino acid 15 from Leu to Phe may alter the packing involving $\alpha$-helix $\mathrm{A}$, which is close to the N-terminus. This bi-helix is implicated in the binding of $\mathrm{NAD}^{+}$to LigA (Georlette et al., 2003; Sriskanda \& Shuman, 2002), supporting our proposal that the temperature sensitivity of LigA251 is a consequence of factors altering the rate of adenylation of the protein.

For many ts mutations, the affected proteins may have a relatively normal function at permissive temperatures, but at the non-permissive temperature the mutation gives rise to structural changes that are significant enough to disrupt the activity of the protein. We suggest that the mutation in LigA251 gives rise to such a phenomenon. Further biochemical and biophysical investigations are required to provide a full appreciation of how the temperaturesensitive mutation affects the molecular structure and biochemical activity of LigA.

\section{ACKNOWLEDGEMENTS}

We thank Sue Butcher for comments on this paper. We are grateful to Dr Lyndsey Black (University of Maryland) for provision of pRBL and to Dr Theonie Georgiou (University of York) and Dr Allison Lewin (UEA) for provision of pRJ345. This work was funded by the BBSRC, the John and Pamela Salter Charitable Trust, the Nuffield Foundation, the Society for General Microbiology and the University of East Anglia.

\section{REFERENCES}

Barany, F. \& Gelfand, D. H. (1991). Cloning, overexpression and nucleotide sequence of a thermostable DNA ligase-encoding gene. Gene 109, 1-11.

Brotz-Oesterhelt, H., Knezevic, I., Bartel, S., Lampe, T., WarneckeEberz, U., Ziegelbauer, K., Habich, D. \& Labischinski, H. (2003). Specific and potent inhibition of $\mathrm{NAD}^{+}$-dependent DNA ligase by pyridochromanones. J Biol Chem 278, 39435-39442.

Dermody, J. J., Robinson, G. T. \& Sternglanz, R. (1979). Conditionallethal deoxyribonucleic acid ligase mutant of Escherichia coli. J Bacteriol 139, 701-704.

Doherty, A. J. \& Suh, S. W. (2000). Structural and mechanistic conservation in DNA ligases. Nucleic Acids Res 28, 4051-4058.

Doherty, A. J., Ashford, S. R., Subramanya, H. S. \& Wigley, D. B. (1996). Bacteriophage T7 DNA ligase - overexpression, purification, crystallization, and characterization. J Biol Chem 271, 11083-11089.

Gellert, M. \& Bullock, M. L. (1970). DNA ligase mutants of Escherichia coli. Proc Natl Acad Sci U S A 67, 1580-1587.

Georlette, D., Blaise, V., Dohmen, C., Bouillenne, F., Damien, B., Depiereux, E., Gerday, C., Uversky, V. N. \& Feller, G. (2003). Cofactor binding modulates the conformational stabilities and unfolding patterns of $\mathrm{NAD}(+)$-dependent DNA ligases 
from Escherichia coli and Thermus scotoductus. J Biol Chem 278, 49945-49953.

Gong, C., Martins, A., Bongiorno, P., Glickman, M. \& Shuman, S. (2004). Biochemical and genetic analysis of the four DNA ligases of mycobacteria. J Biol Chem 279, 20594-20606.

Guex, N. \& Peitsch, M. C. (1997). SWISS-MODEL and the SwissPdbViewer: an environment for comparative protein modeling. Electrophoresis 18, 2714-2723.

Ishino, Y., Shinagawa, H., Makino, K., Tsunasawa, S., Sakiyama, F. \& Nakata, A. (1986). Nucleotide sequence of the lig gene and primary structure of DNA ligase of Escherichia coli. Mol Gen Genet 204, 1-7.

Kaczmarek, F. S., Zaniewski, R. P., Gootz, T. D. \& 12 other authors (2001). Cloning and functional characterization of an $\operatorname{NAD}(+)$ dependent DNA ligase from Staphylococcus aureus. J Bacteriol 183, 3016-3024.

Karam, J. D., Leach, M. \& Heere, L. J. (1979). Functional interactions beween the DNA ligase of Escherichia coli and components of the DNA metabolic apparatus of T4 bacteriophage. Genetics 91, $177-189$.

Kodama, K.-I., Barnes, D. E. \& Lindahl, T. (1991). In vitro mutagenesis and functional expression in Escherichia coli of a cDNA encoding the catalytic domain of human DNA ligase I. Nucleic Acids Res 19, 6093-6099.

Konrad, E. B., Modrich, P. \& Lehman, I. R. (1973). Genetic and enzymatic characterization of a conditional lethal mutant of Escherichia coli K12 with a temperature-sensitive DNA ligase. J Mol Biol 77, 519-529.

Lee, J. Y., Chang, C., Song, H. K., Moon, J., Yang, J. K., Kim, H. K., Kwon, S. T. \& Suh, S. W. (2000). Crystal structure of $\operatorname{NAD}(+)-$ dependent DNA ligase: modular architecture and functional implications. EMBO J 19, 1119-1129.

Lehman, I. R. (1974). DNA ligase: structure, mechanism, and function. Science 186, 790-797.

Modrich, P. \& Lehman, I. R. (1971). Enzymatic characterization of a mutant of Escherichia coli with an altered DNA ligase. Proc Natl Acad Sci U S A 68, 1002-1005.

Petit, M. A. \& Ehrlich, S. D. (2000). The NAD-dependent ligase encoded by yerG is an essential gene of Bacillus subtilis. Nucleic Acids Res 28, 4642-4648.
Ren, Z. J., Baumann, R. G. \& Black, L. W. (1997). Cloning of linear DNAs in vivo by overexpressed T4 DNA ligase: construction of a T4 phage hoc gene display vector. Gene 195, 303-311.

Sambrook, J. \& Russell, D. (2001). Molecular Cloning: a Laboratory Manual, 3rd edn. Cold Spring Harbor, NY: Cold Spring Harbor Laboratory.

Sassetti, C. M., Boyd, D. H. \& Rubin, E. J. (2003). Genes required for mycobacterial growth defined by high density mutagenesis. Mol Microbiol 48, 77-84.

Singleton, M. R., Hakansson, K., Timson, D. J. \& Wigley, D. B. (1999). Structure of the adenylation domain of an $\mathrm{NAD}^{+}$-dependent DNA ligase. Structure 7, 35-42.

Sriskanda, V. \& Shuman, S. (2002). Conserved residues in domain Ia are required for the reaction of Escherichia coli DNA ligase with $\mathrm{NAD}^{+}$. J Biol Chem 277, 9695-9700.

Sriskanda, V., Schwer, B., Ho, C. K. \& Shuman, S. (1999). Mutational analysis of Escherichia coli DNA ligase identifies amino acids required for nick-ligation in vitro and for in vivo complementation of the growth of yeast cells deleted for CDC9 and LIG4. Nucleic Acids Res 27, 3953-3963.

Sriskanda, V., Moyer, R. W. \& Shuman, S. (2001). $\mathrm{NAD}^{+}$. dependent DNA ligase encoded by a eukaryotic virus. J Biol Chem 276, 36100-36109.

Timson, D. J. \& Wigley, D. B. (1999). Functional domains of an $\mathrm{NAD}^{+}$-dependent DNA ligase. J Mol Biol 285, 73-83.

Timson, D. J., Singleton, M. R. \& Wigley, D. B. (2000). DNA ligases in the repair and replication of DNA. Mutat Res 460, 301-318.

Tong, J., Barany, F. \& Cao, W. (2000). Ligation reaction specificities of an $\mathrm{NAD}(+)$-dependent DNA ligase from the hyperthermophile Aquifex aeolicus. Nucleic Acids Res 28, 1447-1454.

Wallis, R., Moore, G. R., James, R. \& Kleanthous, C. (1995). Proteinprotein interactions in colicin E9 DNase-immunity protein complexes. 1. Diffusion-controlled association and femtomolar binding for the cognate complex. Biochemistry 34, 13743-13750.

Wilkinson, A., Day, J. \& Bowater, R. (2001). Bacterial DNA ligases. Mol Microbiol 40, 1241-1248.

Wilkinson, A., Sayer, H., Bullard, D., Smith, A., Day, J., Kieser, T. \& Bowater, R. (2003). $\mathrm{NAD}^{+}$-dependent DNA ligases of Mycobacterium tuberculosis and Streptomyces coelicolor. Proteins Struct Funct Genet 51, 321-326. 